\title{
Whose child is this?: uncovering a Lasallian anthropology of relational belonging and its implications for educating toward the human flourishing of children in faith
}

\author{
Alfred Kah Meng Pang ${ }^{1}$ (D) \\ Accepted: 13 January 2021 / Published online: 30 January 2021 \\ (c) Australian Catholic University 2021
}

\begin{abstract}
In contemporary theological research on childhood, there is considerable interest on the social agency of children. This interest is situated within a global concern for the dignity of children as complex human beings, propelled by the articulation of their participatory rights in the UN Convention on the Rights of the Child (UNCRC). This turn to children and childhood in contemporary theology, I argue, points us to the need for an anthropology of relational belonging that holds out a space for children as agents. I mine the Lasallian tradition to critically retrieve such a communal anthropology that situates the agency of children as learners in a relation of vulnerable belonging to others as God's children and siblings-in-Christ. An implication that arises from this is the importance for religious educators to consider more intentionally the communal dimension of their work in creating a more just world with and for children, promoting their human flourishing.
\end{abstract}

Keywords Children $\cdot$ Agency $\cdot$ Anthropology $\cdot$ Relational belonging $\cdot$ Lasallian

\section{Introduction}

We begin to educate toward the human flourishing of children when we actually recognize their human complexity as relational persons and allow them to transform us in an encounter. This is an insight gained during my ministry placement at a Catholic elementary and middle-school in Boston, when I was facilitating a series of lessons to have students at each grade level reflect on the Stations of the Cross. As I read their reflections, I was moved by their openness in naming significant losses in their lives. These children mentioned missing their grandparents who had passed on. They wondered about why they had to move away from their previous neighbourhoods, hence missing their friends and struggling to

Article revised from paper presented at 2nd International Conference on Catholic Religious Education in Schools, Melbourne Australia, Feb 2020.

Alfred Kah Meng Pang

aplit.tutor@gmail.com

$1 \quad$ Singapore, Singapore 
make new ones. The one that stood out for me was a sixth grader who asked about whether her uncle who survived a gun shooting would forgive the perpetrator.

My encounter with these children did not only highlight the pedagogical importance of making a space for them to be heard for the meanings they create as social agents in religious education. More profoundly, it made me pay attention to children beyond my presumption of their innocence. I was disturbed by the degree of pain that I observed these children had experienced and wished that they should never had to at their ages. At the same time, I was also amazed at their directness and resilience. I began to see children in their humanity and wondered how until this encounter, their complexity had been invisible to me. Yet, to uphold the dignity of children in our work as religious educators demands that we behold this complexity.

In this paper, I consider how an anthropology of relational belonging recoverable from the Lasallian tradition deepens this insight: that is, how we see children as one of us and with us belonging to God is at the heart of what it means to educate toward their flourishing in faith. My discussion proceeds in three movements. First, I review the current turn to children and childhood in theological research, with a focus on the ethical importance for an anthropology of relational belonging that holds out a space for children as agents in Catholic education. Second, I mine the Lasallian tradition to retrieve such an anthropology, critiquing the adult-centric assumptions about children in De La Salle's writings but re-claiming and deepening the mystery of each child as learner in a relation of belonging to community as vulnerable agents. Finally, I consider the implications of this anthropology for religious education in terms of fostering a culture of belonging in schools that respects all children in their differences, engaging their participation in building up God's peaceable reign.

\section{Contemporary turn to children and childhood in theological research}

Over the past two decades or so in the Western academy, there has been considerable interest on children and childhood in contemporary theological scholarship and religious studies (for examples, see Bunge 2001, 2006; Berryman 2017; Brennan 2008; Jensen 2005; Marty 2007; Miller-McLemore 2003; Prevette et al. 2014; Strhan et al. 2017). This interest is in part brought about by a paradigm shift that critically approaches childhood as a social construction; that is, conceptions of childhood are relationally shaped in place and time, through social, cultural, economic and politically processes imbued with power (James and Prout 1997; Wells 2015; for a historical perspective, see also Cunningham 1995; Heywood 2001). The notion of a 'universal' child is rejected as "an impossible fiction" (Montgomery 2009, p. 1). As historian Hugh Cunningham (1995) writes, "children as human beings and childhood as a shifting set of ideas" (p. 1). Thus, the terms 'child' and 'children' are not simply descriptive of younger people in a particular age range, which the United Nations defines as anyone under the age of eighteen. More conceptually, they express a relational significance constituted by the construction of diverse childhoods experienced by these persons at the intersection of biological, developmental, social, economic, cultural and political factors.

A key emphasis in this social constructivist paradigm of childhood is the agency of children. Children are agents as active makers of meaning with those around them in the contextual realities of their lives (Hyde et al. 2010). Agency, according to sociologist David 
Oswell (2013), is "always relational and never a property; it is always in-between and interstitial" (p. 270). In other words, the agency of children is less a capacity that they either have or do not have as separate individuals. It is more dynamically understood within a relational ontology. Children are agents by being human, and whose agency is relationally located in the difference that they make by their embodied presence through variously socially structured ways with and to others. This conceptualization of children as agents is in part propelled by the promulgation of the United Nations Convention on the Rights of the Child (UNCRC) in 1989. Its articulation of children's participation rights has given rise to considerable scholarly interest in engaging the voices of children as social agents in research (Mason and Hood 2011; Shamrova and Cummings 2017). This trend is also reflected in theological research (e.g. Dillen and Pollefeyt 2010; Wall 2010a, b, 2017).

In light of this emphasis on children's agency, religion scholars and theologians are giving more explicit attention to how religious traditions construct their understandings of childhood and children. In the Christian tradition, while the care for children and their instruction in faith are an enduring theme, there is a lack of critical analysis of the anthropology assumed in the theological discourses constructed about childhood and children. As John Wall (2010a) notes:

It is remarkable that, while Christianity has consistently held up humanity's ambiguous nature as simultaneously good and sinful overall, when it comes to children it has generally swung to one extreme or the other. The root of children's dehumanization throughout Christianity has been this tendency to reduce children's ontological natures to a single oversimplified dimension (p. 255).

Herein lies the crucial task to retrieve, critique and reconstruct interpretations in Christian theological anthropology that do not only reflect more diverse and nuance understandings about children and childhood, but also make a space for the agency of children as integral to their dignity as human persons created in God's image and likeness. The theoretical conceptualization of childhood as a social construction pushes theologians to be critical of adultism, which underlies the unidimensional ways in which children are spoken about in Christian anthropology. Adultism as "prejudice in favor of adults" (Young-Bruehl 2012, p. 8) often presumes the passivity of children as unformed adults, rather than as fully human in being "creative agents engaged in creative interaction with the world" (Sturm 1992, p. 158). Adultism reduces the human depth of children to being silent "reflections of adult concerns about the present or as projections of adult concerns for the future" (Ridgely 2011, p. 1). A critique of adultism, then, reclaims a respect for the value of children in and of themselves, as sharing equal dignity with adults as God's beloved creation in what I conceive as an anthropology of relational belonging.

\section{Toward an anthropology of relational belonging}

An anthropology of relational belonging insists on the interconnectedness of children and adults in shared humanity as God's diverse creation. Children and adults share the oneness of life in God; they incarnate God's presence to one another through life together that unfolds socially in historical time and across various cultural settings. An anthropology of relational belonging moves away from an individualistic understanding of agency. It locates children's agency in the context of community that is as much transformed by the 
presence of children as social actors while caring for them. Douglas Sturm (1992) alludes to such an anthropology when arguing for a theology of children's liberation:

Adults and children belong together and contribute to each other's lives. A child, from the very beginning of its presence in the midst of the community, is a center of feeling, thought, and action. Children are not merely a neutral stuff to be shaped and molded through socialization, but are themselves sources of novel possibility and surprise (p. 158).

It is, however, crucial not to discount the social vulnerabilities of children while speaking of them as agents. As children are generally more dependent on adults for protection and care, injustice happens when this dependency is manipulated and exploited within structural relations of adult-centric power that render them socially vulnerable to marginalization (Roche 2009). This social vulnerability extends to how children's capacity for agency can be easily obscured or stifled when they are not heard and seen for who they are.

Yet, this recognition of children's social vulnerabilities demands a prior attention to a primordial vulnerability that all of us share in being relationally human (Jensen 2005). As Wall (2010b) highlights, "The deeper meaning of vulnerability has to do, not with lack of agency, but with openness and relationality to the world" (p. 39). Relational belonging is rooted in an embrace of this deeper sense of vulnerability intrinsic to human interrelatedness. The anthropology that I am proposing situates the agency of children in a communal relation of vulnerable belonging with others unto life in God.

Before I critically retrieve this anthropology of relational belonging from the Lasallian tradition, it is worth highlighting its ethical importance. Contemporary theological interest in children and childhood has reminded us of the biblical mandate to welcome, care and advocate for children as central to Christian discipleship in God's mission (cf. Mark 9: 33-37, 10: 14-16; Matthew 18: 2-6; Luke 9: 48). It has renewed the call to treat children justly as their right to life continues to be systemically marginalized and threatened by structural conditions of violence, poverty, malnutrition and disease (Whitmore and Winwright 1997). As Ethna Regan (2014) argues:

Children have become a new measure of justice for the church ad intra, a measure that will determine our credibility to speak on matters of justice for children, born and unborn, in a world where poor children continue to suffer from having too much to bear and from being given too little to develop properly" (p. 1030, emphasis mine).

This call for an ethic of justice for children is deemed even more important today, in the wake of more recent reports on their sexual abuse by clergy within the Roman Catholic Church. The Catholic Church's ratification of the UNCRC also obliges it to be a trustworthy and credible advocate responsive to the social suffering and well-being of the world's children in faith and action. Relational belonging, in insisting that children are one of us and with us as a community of persons made in God's image, serves as an anthropological foundation for this greater Christian call to work prophetically toward a more just world for their human flourishing.

Educating in faith must also be part of this prophetic work that struggles alongside with children toward a vision of God's justice, whose intention for life's flourishing is constituted in the dignity of our common belonging to one another as God's beloved children. In religious education, this contemporary turn to children and childhood in theology is reflected in these ways: a critical interrogation of images of children and childhood constructed in the Catholic Church's educational documents (Grajczonek 2010); a re-conceptualization of relational-participatory pedagogies that draw out and engage with the voices 
of children as competent subjects (e.g. Dillen 2006, 2007); a greater need to recognize children as spiritual agents and their contributions to shaping the spirituality of adults along the journey of faith formation as a process of accompaniment (e.g. Miller-McLemore 2003, 2010; Yust 2007). These studies reflect a commitment to lift up the agency of children in reconceptualizing pedagogies for religious education. However, a more explicit social engagement with justice for and with children while educating in faith is still needed.

Such engagement must pay critical attention to the wider marketization of education that has socially shaped conditions of relating in schools where religious education takes place. The problem with marketization is in its limiting anthropological vision of the child as burden, client, and future worker in an environment of transactional competitiveness and individualism (Roche 2009). It has also contributed in part to what Chap Clark (2011) analyzes as a culture of abandonment that has systemically isolated children from adults with whom they long for a committed relationship but have learned not to readily trust:

by the time adolescents enter high school, nearly every one has been subjected to a decade or more of adult-driven and adult-controlled programs, systems, and institutions that are primarily concerned with adults' agendas, needs, and dreams (p. 30).

Catholic schools are not immune from the effects of this marketization. Yet, what ought to be reclaimed from a Catholic vision of education is its communal anthropology to counter an individualist and mechanical account of the human as a commodity. Relational belonging refines this sense of the communal by including children as vulnerable agents in their own right, learning and participating with adults to contribute to the common good. The dignity of children's lives lies in their being-in-relation with others, and as they "already are fully alive, fully present, fully endowed with promise in God's world" (Jensen 2005, p. 122). As Clark (2011) further notes, "All kids, regardless of their background, family, ethnicity, gifts or power, are desperate for a society that will help them discover who they are, what gifts and voice they have, and how they belong in a multigenerational community that values all" (p. 186). My conviction is that children flourish when we educate for relational belonging by accompanying them to recognize, embrace and nurture their giftedness in the now and for the life of the world. The Lasallian tradition, as one of many spiritual sources in Catholic education, presses us in this direction as it nourishes an anthropology of relational belonging in a contemplative incarnational vision of educating in faith that is inseparable from the struggle for social justice in solidarity with children.

\section{Retrieving an anthropology of relational belonging in the Lasallian tradition}

The Lasallian tradition originates from John Baptist de La Salle (1651-1719), founder of the Institute of the Brothers of the Christian Schools in seventeenth century France and the patron saint for Christian teachers of the young. What began as the provision of elementary Christian schools to poor children (specifically boys from ages six to twelve years old) in Rheims is today a worldwide educational mission shared by the De La Salle Brothers and lay partners from across different faiths and cultures, and in a network of Lasallian schools and organizations focused on the holistic formation and care of children and youth.

In setting out to articulate an anthropology of relational belonging in the Lasallian tradition, my conviction is that religious charisms of Catholic educational missions emerging from a different historical period can still be relevant and responsive to our 
present realities. They are reservoirs from which "spiritual capital" may be drawn, renewed and witnessed as "the animating, inspirational and dynamic spirit which has empowered the mission of Catholic education internationally" (Grace 2016, p. 48-49). Yet, the creative action of God's spirit that underpins the vitality of these charisms through time demands us to bring them into critical dialogue with the needs of contemporary education, facilitating "an imaginative use of tradition" (Sheldrake 1991, p. 168).

Following an interpretive method of retrieval, critique, and reconstruction (McCarthy 2000), I bring the Lasallian tradition into dialogue with contemporary developments in a theology of childhood and children. What might its contributions be to these developments? How may recent theological research on children and childhood challenge the Lasallian tradition to critique itself and re-imagine its understanding of the humanity of children? My interpretive analysis draws on De La Salle's writings, the Institute's documents, as well as contemporary Lasallian scholarship. Some may question whether my turn to Lasallian scholarship mainly produced by the Brothers internally for the Institute is critically limiting. This is not necessarily the case as these internal sources offer us insights into the Institute's self-understanding and articulation of its charism. Moreover, from my knowledge, these sources are not widely made known to a larger academic community beyond the Lasallian world, and yet their value lies in an insider's perspective of a living developing tradition.

My analysis draws out from these Lasallian sources an anthropology of relational belonging in which each child as student is encountered in faith as God's own and sibling-in-Christ belonging to a communal set of educational relationships in dependent interdependency. Yet, in light of the social constructivist paradigm of childhood, this relational belonging also pushes the Lasallian tradition to critique its own adult-centric lens on the nature of children and childhood, and reclaim a deepened understanding of the mystery of each child as relational learner with agency.

\subsection{Relational belonging and the human child in need of attention}

Paying attention to the child as a whole person is at the heart of Lasallian education As Lasallian scholar Jean-Louis Schneider (2006) writes:

Fidelity to the Spirit is, in the case of John Baptist de La Salle, coupled with another fidelity: fidelity to the [children and] young people confided to us, such as they are. This implies respect for their convictions, attention to all their needs and recognition of the presence of God in them and in their destiny (p. 245).

Attentiveness to the wholeness of children entails attending and responding to their social suffering caused by structural conditions that unjustly treat them as non-beings. This is the crux of a powerful pastoral letter that John Johnston wrote in 1999 as the Institute's Brother Superior-General This letter-entitled On the Defense of Children, the Reign of God, and the Lasallian Mission-catalyzed the incorporation of the UNCRC as integral to the Lasallian mission of education. In this letter, Johnston boldly argued:

the situation of poor children in today's world is an unspeakable scandal that our Lasallian charism invites us to make solidarity with neglected, abandoned, marginalized, and exploited children a particular focus for our mission (Johnston 2016, p. 466). 
He noted that when the human right of children to life is violated in situations of economic exploitation, discrimination, sexual abuse, illiteracy, violence and armed conflict, we "too often close our eyes and mouths and unwittingly play the role of the priest and Levite in the parable of the Good Samaritan" (Ibid., p. 446). The gospel mandate that makes educating the poor a priority must engage in the struggle for the human rights of children as a matter of justice "in accord with what the Reign of God requires" (Ibid., p. 459). It is not only making children facing economic poverty a missional priority. The Lasallian educator must also share in Jesus's indignation at the marginal status of children that has impoverished their lives in society (Johnston 2011).

Johnson's pastoral letter expresses a communal anthropology of relational belonging when he writes that the call to defend and promote children's rights in Lasallian education is to serve as "heralds of human dignity" committed to "building an international communion of persons in which all children can live as the children they have the right to be" (Johnston 2016, p. 480). This echoes the UNCRC's insistence that children are us and with us in one shared humanity. Where Johnson goes further is to ground this anthropology more deeply in a contemplative key that animates an incarnational vision of education: "Jesus comes to us as a poor man because he comes to us as neglected, exploited, abandoned children... We meet Jesus Christ in children when we welcome children as children, when we love and reverence them as they are" (Ibid., p. 478).

This contemplative turn recalls a central tenet in De La Salle's meditations: attentiveness to the human child in dignity stems from a reverence of God's holy presence in children. This reverence is rooted in a twinned dynamic of faith and zeal that characterizes the Spirit of the Lasallian tradition. In his meditation on the Feast of the Epiphany, for example, De La Salle invites educators to follow the example of the Magi, who, in adoring the Infant Child see God's compassion for and companionship with children in their poverty and marginalization:

Recognize Jesus beneath the poor rags of the children whom you have to instruct.

Adore him in them...May faith lead you to [instruct] with affection and zeal, because these children are the members of Jesus Christ (Meditations 96.3, emphasis mine). ${ }^{1}$

This contemplative moment of standing at the manger confronts the educator to not only ask 'What Child Is This?' but also 'Whose Child Is This?'. Underscored is a theological anthropology of relational belonging. Children belong to God not only because they are God created. Rather, it is because God has come to encounter us as a child in Jesus Christ. The radicality of the Incarnation is that God has chosen to entrust God-self to human care and nurture by breaking into history as a child and for the world's children. In the Christ Child, God has come to be with the poor and in the least as a human child. Through the Infant Jesus, God calls educators to a discipleship of solidarity with children as the least and poor. This solidarity is rooted in faith that children already belong to the Body of Christ in and as community, beyond their biological families. Flowing from this faith is zeal as passion for educating all children grounded in God's passionate love that is radically inclusive. For De La Salle, the Christian school is to incarnate this passion and compassion in and through a living community of persons to which children belong.

Rooted in the mystery of the Incarnation, the anthropological foundation of Lasallian education is communal. Relational belonging to children is lived outward with zeal, from a

\footnotetext{
1 Meditations is a reference to De La Salle (1994). Hereafter cited in text as M., followed by the numbering used in this text.
} 
contemplative depth of faith that sees God's presence in human interconnectedness. It situates the human dignity of children relationally in terms of whose they are: as belonging to God, who comes to us in and through children as gift. Children as God's gift are valuable in themselves for who they already are. Yet, the radicality of being gift also lies in who they become through responsible nurture, while bearing God's presence throughout their lifespan in the world. A Lasallian anthropology of relational belonging affirms this dialectic of children as "gift and task" (Miller-McLemore 2003, p. 104). Children as gift "of a new and living social relation" (Wall 2010b, p. 43) call forth a configuration of interdependent relations as community. Lasallian anthropology further structures teacher-children relationships along two interrelated dimensions: as siblings-in-Christ and God's children.

\subsubsection{Children as siblings-in-Christ}

Seeing and welcoming children as younger siblings-in-Christ is a significant aspect of Lasallian education. Lasallian scholar John Crawford (Crawford 2015) has proposed "a sibling model of education" as "the most significant element of the Lasallian charism" (p. 55). He writes, "For those called to teach, we are to be brothers and sisters to our younger siblings, if we are to imitate Jesus' praxis" (Ibid., p. 49). This sibling model is traced back to how De La Salle and his earliest followers understood the lay character of their fraternal relations as 'Brothers of the Christian Schools.' The term 'Brother' is not simply a religious title. It intentionally marks a way of being teacher to student in a "pedagogy based on mutually respectful relationships" (Rummery 2013, p. 89). It is this founding inspiration of being an elder sibling to another that Crawford (2015) wishes to extend to all teachers:

This Lasallian ethos works toward claiming our common inheritance as brothers and sisters of Jesus Christ. Lasallian teachers are not about their own importance in some hierarchically "more significant" place than their students. Rather Lasallian siblinghood is about assuring that the young will take their places side-by-side with us in our shared human dignity as brothers and sisters in the eyes of our loving God (p. $50)$.

Common siblinghood-in-Christ structures a communal anthropological foundation for the mutuality between teacher and student. This mutuality underlines not only the respect that the teachers and students have for one another. It also highlights the bi-directional relationship between them in which he teacher as an elder is also learning from their students as younger siblings.

In the context of teaching children, however, conceptions of mutuality are complicated by the power differential between teacher and student, as well as the asymmetrical relationship between children and adults due to biological and psychological factors (MillerMcLemore 2003, p. 128-129). Even when children as agents do form and shape adults in more ways than they realize (Miller-McLemore 2017, p. 54), they still require guidance from responsible adults with more experience, and who generally have more social power to advocate for structural changes to promote their well-being. In this regard, fostering a relation of mutuality with children is not necessarily opposed to this asymmetry in power, but requires it as "a temporary inequity between persons-whether of power, authority, expertise, responsibility, or maturity - that is moving toward but has not arrived at genuine mutuality" (Miller-McLemore 2003, p. 130).

Lasallian anthropology, in fact, affirms this more dynamic understanding of mutuality within the power differential between children and adults in the process of education. 
Recognizing children as younger siblings-in-Christ does not call for an abdication of teacher authority. Rather, it demands that the teacher reflect as a responsible adult on how this authority is being used to positively influence children in life-giving ways. This pastoral sensitivity to the teacher's use of power is a key theme in De La Salle's pedagogical writings. He rejected any coercive display of power by teachers. On the issue of school discipline, for example, he insisted that "children must not be corrected like animals, but like reasonable persons" (M. 204.1, emphasis mine). The Conduct of the Christian Schools also listed actions that would make teachers unbearable to children; for example, "the teacher immediately rejects the reasons and excuses of children and is not willing to listen to them at all;" "the teacher, not mindful of personal faults, does not know how to sympathize with the weaknesses of children, and so exaggerates their faults too much. This is the situation when a teacher reprimands them or punishes them and acts as though dealing with an insensible instrument rather than with a creature capable of reason" (p. 136, emphasis mine). ${ }^{2}$

De La Salle's pedagogical wisdom is found in his insistence on a balance between firmness and gentleness in the teacher-child relationship: "that firmness may not degenerate into harshness and that gentleness may not degenerate into languor and weakness" (Conduct, p. 135). This wisdom is grounded in an incarnational spiritual vision of common siblinghood-in-Christ. The teacher as an elder sibling has the greater responsibility in guiding and drawing children to God by following the example of Christ's passion and compassion in educational practice: "Every day you have poor children to instruct. Love them tenderly...following in this the example of Jesus Christ" (M. 166.2, emphasis mine). Recognizing children as younger siblings-in-Christ makes a claim on teachers to critically reflect as adults on how they are using their authority to lift up the human dignity that all share equally before God on their journey together as God's children.

\subsubsection{Children as God's children}

The intrinsic human dignity of children is located transcendentally in their identity as God's children. De La Salle writes:

Consider this an honour for you and look upon the [poor] children God has entrusted to you as the children of God himself. Have much more solicitude for their education and instruction than you would have for the children of a king (M. 133.2).

For him, "children of God" as a theological category is not an abstract ideal. His insight is that for the category to be meaningful, one ought to take seriously the social realities of actual children and their struggles. Hence, De La Salle was realistic about the impact that social neglect had on poor children while affirming their fundamental goodness. On the one hand, he wrote than in being "abandoned to their own will," children were susceptible to negative influence from the company they keep "because their minds have not developed yet and they are not capable of much reflection" (M. 203.2). Yet, on the other hand, children were also perceived as "the most innocent part of the Church, and usually the best disposed to receive the impressions of grace" (M. 205.3). What De La Salle meant by 'innocence' is a foundational goodness "rooted firmly in a deeper, longer faith perspective

\footnotetext{
${ }^{2}$ Reference is from De La Salle (1996). Subsequently cited in text as Conduct, followed by the page number in this translation.
} 
that looks beyond and behind the challenging and often disturbing realities prevalent outside, and sometimes inside, the classrooms of the time" (Van Grieken 2008, p. 363). His insistence on the dignified nobility and equality of even poor children as God's children is significant, especially in seventeenth century France where the social hierarchy between the rich and poor was strictly maintained. This common dignity is the foundation for the teacher to love and know each child as s/he is.

For De La Salle, children are not miniature adults; rather, they are growing to become adults as grown up children of God. As Lasallian scholar George Van Grieken (2008) notes:

It would be accurate to say that he [De La Salle] did not have any romantic or idealistic ideas about children. Forty years with the poor would quickly erode the best of intentions in that regard. Instead, De La Salle gave children their due, recognizing both their limitations and their strengths, and setting their vocation in the midst of their experience. Children have a vocation to see themselves as part of the world around them, and they have a God-given right to be treated with a respect that reaches beyond their years, drawing them forward to live into the deeper version of their vocation as a child of God (p. 368-369).

From a Lasallian standpoint, educating in faith is a process of accompanying children to grow and become who they already are as children of God, and for life as service in the world.

\subsection{Critical assessment of De La Salle's understanding of the child's nature}

De La Salle's writings on children are, however, shot through with paradox. His conception about the child's nature may strike contemporary readers as arguably paternalistic. On the one hand, he emphasizes their human dignity in stating that "people, and even children, are endowed with reason and must not be corrected like animals, but like reasonable persons" (M. 204.1, emphasis mine). On the other hand, he also writes: not only are children's minds "more dull," they "can easily be led into sin" as "they have little use of their reason, and because nature is consequently more lively in them and strongly inclined to enjoy the pleasures of the senses" (M. 197.1, 56.2). The most startling description of the nature of children is probably found in Meditation 197:

It can be said that children at birth are like a mass of flesh. Their minds do not emerge from the matter in them except with time and become refined only little by little. As an unavoidable consequence, those who are ordinarily instructed in the schools are not yet able by themselves to understand easily the Christian truths and maxims. They need good guides and visible angels to help them learn these things. [...] If this help is not given, they often remain all their lives insensitive and opposed to thoughts of God and incapable of knowing and appreciating them.

Hence, children require the moral guidance of teachers "so that they are no longer...tossed here and there, no longer turned around by every wind of doctrine, by deceit, and trickery, whether through the companions with whom they associate, or men leading them into falsehood by their evil proposals" (M. 205.3).

De La Salle's language about children of course reflects the context of his time. On the one hand, it was progressive in echoing a pre-scientific psychological understanding of children. Yet, on the other hand, it assumed the pervasive influence of an Augustinian 
anthropology that had conceived the child as "born marked and even corrupted by original sin, which inclined him or her naturally to evil" (Hengemüle 2016, p. 132). In light of the critique against adultism in contemporary research on childhood, I contend that a key limitation in De La Salle's theology of child is his assumption that the child is a rational adultin-the-making. His language constructs the child as somewhat being less than the rational adult European white male, who has historically been privileged in the West as normative of a full human being. To the extent that this assumption is left unchallenged, the Lasallian tradition risks falling prey to paternalistic approaches in education that obscures the complex agency of children in their various contexts while purporting to uphold their human dignity. A commitment to relational belonging that truly includes children demands this challenge.

Notwithstanding these criticisms, two aspects of De La Salle's theological thought about the nature of children are still relevant and worth reclaiming. First, the view that children are sinners and sinned against. While we ought to be cautious against seeing children as exclusively sinful, we should not go to the other extreme of viewing them as pure and blameless. The latter ironically diminishes the moral responsibility of children as agents (Bunge 2007; Miller-McLemore 2003). Despite the Augustinian strain in his theology of sin, De La Salle was careful to balance it with the hope-filled possibility that children can overcome sin and grow in virtue because they are "usually the best disposed to receive the impressions of grace" (M. 205.3). His theology of sin is also fundamentally relational. Noteworthy is his association of the sins committed by children with the company they keep that is as relevant today:

The results of this condition are regrettable, for these poor children, accustomed to lead an idle life for many years, have great difficulty adjusting when it comes time for them to go to work. In addition, through association with bad companions they learn to commit many sins which later on are very difficult to stop, because of the persistent bad habits they have contracted over such long time (M. 194.1).

More significantly, De La Salle also alluded to the structural dimension of sin committed against children due to social neglect in conditions of poverty (Hengemüle 2016). What ought to be reclaimed and developed is precisely this awareness of how children are more often sinned against through the wounding effects of adult neglect, rejection, and violence that become internalized throughout their lives. It is this dimension of social sin committed against children as God's children and sibling-in-Christ that sharpens the prophetic dimension of Lasallian education. Educating children in faith as moral guidance is not separate from the struggle for justice that promotes their human flourishing.

Second, a developmental anthropology that grounds children's growth as persons in relationships. While De La Salle is rightly critiqued for his assumption about children as unformed adults-in-the-making, this should not negate the fact that children are developing beings. Nor is this critique rejecting the future of children to become adults. I highlight here an important argument that sociologist Emma Uprichard (2008) has advanced: children are both "being and becomings" (p. 303). This serves to balance what appears to be overemphasis in childhood studies on the being of children as agents at the expense of their growth through time. As she contends, "Looking forward' to what a child 'becomes' is arguably an important part of 'being' a child" (p. 306). In other words, the temporal dimension of each child's 'being' implies her or his 'becoming' as an open-ended dynamic self, composing who s/he is interdependently with others through time. From this standpoint, "[c]hildren have the right to become adults and experience their childhood as children who will be future adults" (p. 306). 
It is this conception of children as "being and becomings" that is recoverable from and worth affirming in De La Salle's developmental anthropology. In fact, De La Salle goes further theologically to ground the 'being' of children in 'becoming' "heirs to the Kingdom [which] called for and required preparing them to be a useful part of human society" through education (Hengemüle 2016, p. 165; see also M. 201.2). His developmental anthropology situates the educational growth of children in a relational frame of belonging to God as the ground of life for their social beings and becomings. For De La Salle, the concern is not simply the right of children to survive well into adulthood. Of critical importance is the future of children to become who they already are as children of God, in love for God present in the neighbour as a fellow sibling-in-Christ. This future must be the present task of educating our children in faith.

\subsection{Renewing the mystery of the child as learner}

In Lasallian anthropology, children as learners are not only psychological and sociological subjects. Ultimately, in light of the Incarnation, they are encountered as mystery, a dimension revitalized and renewed in Karl Rahner's (1977) theology of childhood (Pang 2016). Fundamentally, Lasallian anthropology recognizes children as spiritual beings who reveal the mystery of our common belonging to God as children of God and siblings-in-Christ. To speak about children as mystery, however, is not to mystify and minimize situations of impoverishment suffered by them. Properly understood, mystery re-positions the child as learner from being seen as an object that requires fixing to a living subject who is fully present and desires to be engaged into loving. It informs and deepens one's conviction that problems affecting children are more adequately addressed when there is a willingness and readiness to know them as full persons in their situated relational complexity. Mystery admits their complexity as gift and task, in their being and becoming as continual learners in a vulnerable relation of belonging to others as agents. It does not turn us away from the reality of children's lives. Rather, from a Lasallian standpoint, the mystery of each child as learner carries educators toward a more-ness in that very reality in faith, which cultivates in teaching "an uncanny ability always to suspect that in persons and events there is more than meets the eye" (Salm 2017, p.154). This faith is rooted in God who comes as poor in the Christ Child, which underlines the prophetic dimension in Lasallian education that envisions the call to teaching children as inseparable from working for justice to promote their human flourishing.

\section{Implications for religious education}

At the heart of what relational belonging means for a Lasallian vision of education is this: that we belong to one another as God's children is who we begin as and learn to become through education for life. As Lasallian scholar Pierre Ouattara (2013) writes, "Just as the baby begins its existence with the welcome it receives into the world, so education contributes to teaching the child how to find and to create hospitality from within" (p. 294). Existentially, it is not sufficient to socialize children into the norms of a culture. Education must also engage children as agents to "participate in the construction of the social life" and "live in reciprocal hospitality with others" (p. 287).

An important implication of this vision is for religious educators to consider more intentionally the communal dimension of their work in creating a more just world with and for 
children. This could begin with religious educators critically examining how their curricular and pedagogical practices contribute to creating a culture of belonging in schools that respects all children in their differences, engaging their participation in building up God's peaceable reign. Teaching the sacraments to elementary school children, for example, would go beyond mere information giving in preparation for their reception in church. It must also intentionally invite children to reflect on how sharing in the church's sacramental obliges them to participate in the life of God through service in their families and schools. This would call a greater integration of religious education with school-wide community service projects that teachers could engage children in through age-appropriate ways. A culture of belonging is also fostered in the classroom when religious educators create spaces that welcome the perspectives of children. This could take the form of having children name their fears and hopes, their questions and observations of what they are noticing in their neighborhoods, as well as what is important for them which they wish to bring to God.

Fundamentally, relational belonging compels religious educators (all teachers in fact) to reframe their manner of relating to children as "pilgrims not because they are on their way somewhere, not because they are growing up to be somebody, but because they already are somewhere and somebody" (Jensen 2005, p. 53). It demands that teachers learn to listen as a spiritual practice of holy wonder. Such listening is receptive to the mystery of each child who can and does surprise. Religious educators listen to and with children in-to having their perceptions challenged and even overturned, to un-see their own adultism and re-envision new possibilities of relating in teaching. Listening as holy wonder demands humility that opens the adult religious educator to being formed and transformed by children, through whom God's Spirit also speaks as our siblings-in-Christ for the transformation of our world. Listening to learn from children is learning to teach justly.

\section{Conclusion}

As I conclude this article, the world is reeling from the effects of a global pandemic caused by Covid-19. It is a drastically different world from when I first presented this as a paper last February in Melbourne at the International Conference on Catholic Religious Education in Schools. Since then, the education of our children has been disrupted. There is the ongoing concern if and how schools can be opened without compromising the safety of children and teachers. Where schools are closed, not every child has access to digital technology to learn remotely. Teachers are also experiencing the stress that comes from having to teach remotely and/or shuffle between online and in-person teaching. During lockdowns, some who are parents find themselves having to care for their own children at home while teaching other people's children.

The pandemic has also thrown the social marginalization of children into sharp relief. It is striking to observe that only two prime ministers (and both women) - Erna Solberg from Norway and Jacinda Ardern from New Zealand-held a special press conference for children to explain about the virus and address their questions directly as citizens. In the United States, racial health disparities have caused people of colour, particularly from African-American and Latinx/ Hispanic communities, to suffer from a disproportionately high rate of death due to the virus (Wingfield 2020). They also face a higher risk of falling ill because many are low-wage workers who do not have the privilege to telework (Blow 2020). What is unspoken is that some of these people are providers and caregivers 
to children in their families. Children of color risk losing their parents to the pandemic. Children from impoverished communities of colour in the United States do not even have access to clean water to wash their hands (Worland 2020). Furthermore, under the Trump administration, the spread of the virus is being used to push for the incarceration and deportation of migrant children and/or their parents at the U.S.-Mexico border (Hesson and Rosenberg 2020). In all of these, the social vulnerabilities of children tied to existing social inequalities that Covid-19 has exacerbated remain relatively less visible to the public.

Yet, in the midst of this social disruption, it is all the more crucial to commit deeply to a prophetic vision of educating for justice rooted in a preferential option for children. What this pandemic has clearly revealed is our interconnectedness as human beings who are inherently social and communal. The pain of social distancing reflects our longing to belong and connect as community. And our communities include children, who are agents in a vulnerable relation of belonging to one shared humanity as God's creation. During this pandemic, it is vital that religious educators commit to the communal work of being present to children in ways that bring comfort and inspire courage. The challenge is also for religious educators to become advocates for children, especially in situations where their well-being is being compromised. In this time of social upheaval where children are still the least among the poor, the Lasallian tradition impels all Christian educators to incarnate the prophetic vision of Jesus in the Gospel, which Judith Gundry-Volf (2001) has provocatively described:

Jesus did not just teach how to make an adult world kinder and more just for children; he taught the arrival of a social world in part defined by and organized around children...He invited the children to come to him not so that he might initiate them into the adult realm but so that they might receive what is properly theirs - the reign of God (p. 60).

The Lasallian tradition grounds this prophetic stance in an interior kneeling (Ouattara 2013) that disposes the educator spiritually to see "Jesus beneath the poor rags of the children whom you have to instruct" (M. 96.3). Such is an interior kneeling that summons one to trust - that what we regard to be little in our best efforts to educate in faith during this pandemic do have an impact beyond what we can see because nothing is wasted in God. This trust is found in a mighty hope that paradoxically rests on God choosing to come to us in the smallness of a child, entrusting God-self to human care. This trust is with prophetic hope in the promise that God will be there to meet us in the lives of children because in coming as a poor child in Jesus Christ, God stands in solidarity with them as the least and marginalized.

\section{Compliance with ethical standards}

Conflict of interest The author declares that they have no conflict of interest to disclose.

\section{References}

Berryman, J. W. (2017). Becoming like a child: The curiosity of maturity beyond the norm. New York: Church Publishing.

Blow, C.M. (2020). Social Distancing Is a Privilege. The New York Times. Retrieved from Rhttps://www. nytimes.com/2020/04/05/opinion/coronavirus-social-distancing.html. Accessed 5 April 2020. 
Brennan, P. M. (Ed.). (2008). The vocation of the child. Grand Rapids: William B. Eerdmans Publishing Company.

Bunge, M. J. (Ed.). (2001). The child in Christian thought. Grand Rapids: William B. Eerdmans Publishing Company.

Bunge, M. J. (2006). The child, religion, and the academy: Developing robust theological and religious understandings of children and childhood. The Journal of Religion, 86(4), 549-579.

Bunge, M. J. (2007). Beyond children as agents or victims: Reexamining children's paradoxical strengths and vulnerabilities with resources from Christian theologies of childhood and child theologies. In T. Wyller \& U. S. Nayar (Eds.), The given child: The religions' contribution to children's citizenship (pp. 27-50). Göttingen: Vandenhoeck \& Ruprecht.

Clark, C. (2011). Hurt 2.0: Inside the world of today's teenagers. Grand Rapids: Baker Academic.

Crawford, J. M. (2015). Lasallian pedagogy: Who we are is what we teach. AXIS: Journal of Lasallian Higher Education, 6(2), 47-71.

Cunningham, H. (1995). Children and childhood in western society since 1500. London: Longman.

De La Salle, J. B. (1994). Meditations by John Baptist de La Salle. Landover: Lasallian Publications.

De La Salle, J. B. (1996). The conduct of the Christian schools. Landover: Lasallian Publications.

Dillen, A. (2006). Children between liberation and care: ethical perspectives on the rights of children and parent-child relationship. International Journal of Children's Spirituality, 11(2), 237-250.

Dillen, A. (2007). Religious participation of children as active subjects: Toward a hermeneutical-communicative model of religious education in families with young children. International Journal of Children's Spirituality, 12(1), 37-49.

Dillen, A., \& Pollefeyt, D. (Eds.). (2010). Children's voices: Children's perspectives in ethics, theology and religious education. Leuven: Utigeveru Peeters.

Grace, G. (2016). Faith, mission and challenge in Catholic education: The selected writings of Gerald grace. New York: Routledge.

Grajczonek, J. (2010). How shall we know them? Part 1: The construction of 'child' and 'childhood' in official church educational documents. Journal of Religious Education, 58(2), 9-18.

Gundry-Volf, J. M. (2001). The least and the greatest: Children in the new testament. In M. J. Bunge (Ed.), The child in Christian thought (pp. 29-60). Grand Rapids: William B. Eerdmans Publishing Company.

Hengemüle, E. (2016). Lasallian education: What kind of education is it? Minnesota: Institute for Lasallian Studies of Saint Mary's University.

Hesson, T., \& Rosenberg, M. (2020). U.S. deports 400 migrant children under new coronavirus rules. Reuters. Retrieved from https://www.reuters.com/article/us-health-coronavirus-usa-deportations/u-s-depor ts-400-migrant-children-under-new-coronavirus-rules-idUSKBN21P354. Accessed 8 April 2020.

Heywood, C. (2001). A history of childhood: Children and childhood in the west from medieval to modern times. Cambridge: Polity.

Hyde, B., Yust, K., \& Ota, C. (2010). Editorial: Defining childhood at the beginning of the twenty-first century: Children as agents. International Journal of Children's Spirituality, 15(1), 1-3.

James, A., \& Prout, A. (Eds.). (1997). Constructing and reconstructing childhood: Contemporary issues in the sociology of childhood (2nd ed.). London: Falmer.

Jensen, D. H. (2005). Graced vulnerability: A theology of childhood. Cleveland: The Pilgrim Press.

Johnston, J. (2011). Jesus was indignant: Are we? [2001]. AXIS: Journal of Lasallian Higher Education, $2(1), 45-50$.

Johnston, J. (2016). On the defense of children, the reign of god, and the Lasallian Mission [January 1, 1999]. The Pastoral Letters of Br. John Johnston, FSC: 1986-2000 (pp. 443-480). Napa, CA: Lasallian Resource Centre.

Marty, M. E. (2007). The mystery of the child. Grand Rapids: William B. Eerdmans Publishing Company.

Mason, J., \& Hood, S. (2011). Exploring issues of children as actors in social research. Children and Youth Services Review, 33, 490-495.

McCarthy, M. (2000). Spirituality in a postmodern era. In J. Woodward \& S. Pattison (Eds.), The Blackwell reader in pastoral and practical theology (pp. 192-206). Malden, MA: Blackwell Publishers.

Miller-McLemore, B. J. (2003). Let the children come: Reimagining childhood from a Christian perspective. San Francisco: Jossey-Bass.

Miller-McLemore, B. J. (2010). Children's voices, spirituality, and mature faith. In A. Dillen \& D. Pollefeyt (Eds.), Children's voices: Children's perspectives in ethics, theology and religious education (pp. 17-48). Leuven: Uitgeveru Peeters.

Miller-McLemore, B. J. (2017). Childhood: The (often hidden yet lively) vocational life of children. In K. A. Cahalan \& B. J. Miller-McLemore (Eds.), Calling all years good: Christian vocation throughout life's seasons (pp. 38-62). Grand Rapids: William. B. Eerdmans. 
Montgomery, H. (2009). An introduction to childhood: anthropological perspectives on children's lives. Malden, MA: Wiley.

Oswell, D. (2013). The agency of children: From family to global human rights. Cambridge: Cambridge University Press.

Ouattara, P. (2013). The Lasallian service of education: A means of salvation for today? In P. M. Gil \& D. Muñoz (Eds.), Lasallian studies no. 17: That your school runs well: approach to Lasallian educational model (pp. 283-299). Rome: International Council of Lasallian Research and Resources.

Pang, A. K. M. (2016). What child is this? A Rahnerian interpretation of the child in Lasallian pedagogy. AXIS: Journal of Lasallian Higher Education, 7(3), 83-94.

Prevette, B., White, K. J., Ewell, C. R. V., \& Konz, D. J. (Eds.). (2014). Theology, mission and child: Global perspectives. Oregon: Wipf and Stock Publishers.

Rahner, K. (1977). Ideas for a theology of childhood [1963]. In D. Bourke (Ed.), Theological investigations (Vol. 8, pp. 33-50). New York: Seabury.

Regan, E. (2014). Barely Visible: The Child in Catholic Social Teaching. Heythrop Journal, 55(6), 1021-1032.

Ridgely, S. B. (Ed.). (2011). The study of children in religions: A methods handbook. New York: New York University Press.

Roche, M. M. D. (2009). Children, consumerism and the common good. Lanham: Lexington Books.

Rummery, G. (2013). Role of the community in Lasallian education. In P. M. Gil \& D. Muñoz (Eds.), Lasallian studies no. 17: That your school runs well: Approach to Lasallian educational model (pp. 79-89). Rome: International Council of Lasallian Research and Resources.

Salm, L. (2017). The Lasallian Educator in a Shared Mission. AXIS: Journal of Lasallian Higher Education, $8(1), 145-157$.

Schneider, J.-L. (2006). Making the Lasallian Charism live today. In International Council for Lasallian Studies \& A. P. Marron (Eds.), Lasallian studies no. 13: The Lasallian Charism (pp. 233-264). Rome: Brothers of the Christian Schools Generalate.

Shamrova, D. P., \& Cummings, C. E. (2017). Participatory Action Research (PAR) with children and youth: An integrative review of methodology and PAR outcomes for participants, organizations, and communities. Children and Youth Services Review, 81, 400-412.

Sheldrake, P. (1991). Spirituality and history: Questions of interpretation and method. London: SPCK.

Strhan, A., Parker, S. G., \& Ridgely, S. (Eds.). (2017). The bloomsbury reader in religion and childhood. London: Bloomsbury Academic.

Sturm, D. (1992). On the suffering and rights of children: Toward a theology of childhood liberation. Cross Currents, 42(2), 149-173.

Uprichard, E. (2008). Children as 'being and becomings': Children, childhood and temporality. Children and Society, 22, 303-313.

Van Grieken, G. (2008). Soul for soul: The vocation of the child in Lasallian pedagogy. In P. M. Brennan (Ed.), The vocation of the child (pp. 357-380). Grand Rapids: William B. Eerdmans Publishing Company.

Wall, J. (2010a). Childism and the Ethics of Responsibility. In A. Dillen \& D. Pollefeyt (Eds.), Children's voices: Children's perspectives in ethics, theology and religious education (pp. 237-265). Leuven: Uitgeveru Peeters.

Wall, J. (2010b). Ethics in light of childhood. Washington, DC: Georgetown University Press.

Wall, J. (2017). Children's rights: Today's global challenge. New York: Rowan \& Littlefield.

Well, K. (2015). Childhood in a global perspective. Malden, MA: Polity Press.

Whitmore, T. D., \& Winwright, T. (1997). Children: An undeveloped theme in catholic teaching. In M. A. Ryan \& T. D. Whitmore (Eds.), The challenge of global stewardship: Roman catholic responses (pp. 161-185). Notre Dame: University of Notre Dame Press.

Wingfield, A. H. (2020). The disproportionate impact of covid-19 on Black Health Care Workers in the US. Harvard Business Review. Retrieved from https://hbr.org/2020/05/the-disproportionate-impact-ofcovid-19-on-black-health-care-workers-in-the-u-s\#comment-section. Accessed 14 May 2020.

Worland, J. (2020). America's clean water crisis goes far beyond flint. There's no relief in sight. TIME. Retrieved from https://time.com/longform/clean-water-access-united-states/. Accessed 20 Feb 2020.

Young-Bruehl, E. (2012). Childism: Confronting prejudice against children. London: Yale University Press.

Yust, K. M. (2007). Childhood and spiritual wisdom: Constructing a critical conversation for the 21 st century. International Journal of Children's Spirituality, 12(1), 5-8.

Publisher's Note Springer Nature remains neutral with regard to jurisdictional claims in published maps and institutional affiliations. 